\title{
Facile Synthesis of Porous Zn-Sn-O Nanocubes and Their Electrochemical Performances
}

\author{
Bo $\mathrm{Li}^{1} \cdot$ Xiaomin $\mathrm{Li}^{1} \cdot$ Jiantao Zai ${ }^{1} \cdot$ Xuefeng Qian ${ }^{1}$
}

Received: 31 August 2015/Accepted: 27 October 2015/Published online: 21 December 2015

(C) The Author(s) 2015. This article is published with open access at Springerlink.com

\begin{abstract}
Porous $\mathrm{Zn}-\mathrm{Sn}-\mathrm{O}$ nanocubes with a uniform size were synthesized through a facile aqueous solution route combined with subsequent thermal treatment. The chemical composition, morphology, and microstructure of $\mathrm{Zn}-\mathrm{Sn}-\mathrm{O}$ nanocubes, which have significant effects on the lithium storage performances, were easily tuned by adjusting the calcination temperature in preparation processes of $\mathrm{ZnSn}(\mathrm{OH})_{6}$ solid nanocubes. Further studies revealed that porous $\mathrm{Zn}-\mathrm{Sn}-\mathrm{O}$ nanocubes prepared at $600{ }^{\circ} \mathrm{C}$ exhibited a good rate capability and a high reversible capacity of $700 \mathrm{mAh} \mathrm{g}^{-1}$ at a current density of $200 \mathrm{~mA} \mathrm{~g}^{-1}$ after 50 cycles, which may be a great potential as anode materials in Lithium-ion batteries.
\end{abstract}

Keywords $\mathrm{Zn}-\mathrm{Sn}-\mathrm{O} \cdot$ Nanocubes $\cdot$ Porous $\cdot$ Lithium-ion batteries

\section{Introduction}

Lithium-ion batteries (LIBs), currently as versatile power sources for various portable electronics, are now considered for applications in electric or hybrid electric vehicles [1-6]. Such applications require LIBs of high power, high energy density, long cycle life, excellent safety, low toxicity, and low cost $[1,7,8]$. To meet these requires, a great deal of efforts have been made to take a further step in anode electrode materials with superior performances [9-15]. Among various developed anode materials, Snbased oxide compounds, including $\mathrm{SnO}_{2}, \mathrm{ZnSnO}_{3}$, $\mathrm{CoSnO}_{3}, \mathrm{Zn}_{2} \mathrm{SnO}_{4}$, and so on, have attracted an extensive attention as potential substitutes for graphite anodes because of their higher theoretical capacity [16-21].

Jiantao Zai

zaijiantao@sjtu.edu.cn

$\triangle$ Xuefeng Qian

xfqian@sjtu.edu.cn

1 School of Chemistry and Chemical Engineering and State Key Laboratory of Metal Matrix Composites, Shanghai Jiao Tong University, Shanghai 200240,

People's Republic of China
Unfortunately, the practical application of Sn-based oxide anode materials is usually hindered by drastic volume change of $300 \%$ during $\mathrm{Li}^{+}$insertion/extraction process, which results in very rapid capacity decay and pulverization of electrodes [7, 16, 22, 23]. Fabrication of porous nanostructures is one of the most effective methods to solve the problem and improve the cycle performance, because the local empty space in porous structures can partially accommodate the large volume change [24, 25]. In past few years, porous nanostructures based on Snbased oxides were usually prepared through chemical vapor deposition, hydrothermal reaction, hard or soft template method, and so on [26-30].

Although the electrochemical performances of porous Sn-based oxide anodes have been improved a lot, the preparation procedures are usually complicated and costly. It is still a challenge to explore a facile approach for fabricating porous Sn-based oxide anode materials with controllable morphology and good electrochemical properties for practical applications. Herein, porous $\mathrm{Zn}-\mathrm{Sn}-\mathrm{O}$ nanocubes with different morphology and microstructure were synthesized by sintering $\mathrm{ZnSn}(\mathrm{OH})_{6}$ solid nanocubes at different temperatures. The obtained porous $\mathrm{Zn}-\mathrm{Sn}-\mathrm{O}$ nanocubes exhibited high reversible capacity and good rate capability. 


\section{Experimental Section}

\subsection{Synthesis of Porous $\mathrm{Zn}-\mathrm{Sn}-\mathrm{O}$ Nanocubes}

In a typical procedure, $2.876 \mathrm{~g}$ of $\mathrm{ZnSO}_{4} \cdot 7 \mathrm{H}_{2} \mathrm{O}$ was dissolved into $150 \mathrm{~mL}$ deionized water, and then $2.848 \mathrm{~g}$ of $\mathrm{Na}_{2} \mathrm{SnO}_{3} \cdot 4 \mathrm{H}_{2} \mathrm{O}$ was added under continuous stirring at room temperature. After stirring for $5 \mathrm{~h}$, the resulted white precipitation was collected by centrifuging, washing with deionized water for several times, and drying in air at $80^{\circ} \mathrm{C}$. Finally, porous $\mathrm{Zn}-\mathrm{Sn}-\mathrm{O}$ nanocubes were obtained by sintering the as-prepared white precursors at respective 500,600 , and $700{ }^{\circ} \mathrm{C}$ for $2 \mathrm{~h}$ in air with a heating rate of $1{ }^{\circ} \mathrm{C} \min ^{-1}$.

\subsection{Characterizations}

Morphology of the obtained products was characterized by field emission scanning electron microscope (FESEM, JSM-7401F) and transmission electron microscope (TEM, JEOL, JEM-2100). Powder X-ray diffraction (XRD) was recorded on a Shimadzu XRD-6000 with $\mathrm{Cu}-\mathrm{K} \alpha$ radiation, in which the voltage and current of X-ray tube are of $40 \mathrm{kV}$ and $30 \mathrm{~mA}$, respectively. Thermogravimetric analysis (TGA) was performed on a SDT Q600 thermoanalyzer (DSC-TGA, TA, USA) in air. The specific surface area and pore size distribution were measured by a NOV A2200e analyser (Quantachrome, USA).
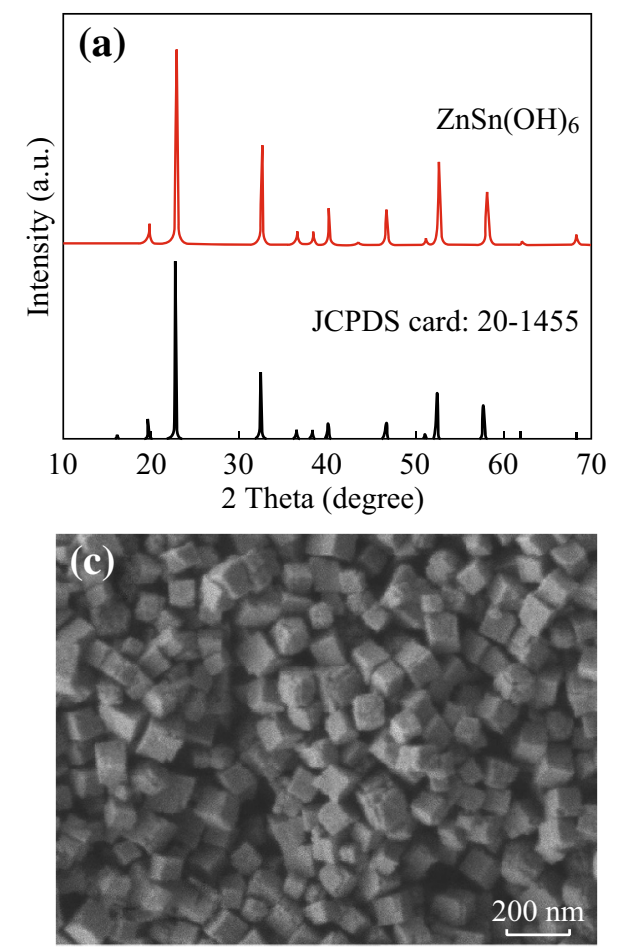

\subsection{Electrode Fabrication}

Working electrode was fabricated as follows: First, porous $\mathrm{Zn}-\mathrm{Sn}-\mathrm{O}$ nanocubes $(70 \mathrm{wt} \%)$, Super-P carbon black (15 wt\%), and sodium carboxymethyl cellulose (CMC, 15 $\mathrm{wt} \%$ ) were mixed in water to form a slurry. Then, the slurry was spread onto a $\mathrm{Cu}$ foil by a doctor blade method, followed by drying in vacuum at $80{ }^{\circ} \mathrm{C}$ for $8 \mathrm{~h}$. A lithium foil acted as both the counter electrode and reference electrode, and a microporous polypropylene membrane (Celgard 2500) was used as separator. Then, CR2016 coin cells were assembled in an argon-filled glove box with moisture and oxygen contents below $1 \mathrm{ppm}$. The electrolyte was $1 \mathrm{M}$ of $\mathrm{LiPF}_{6}$ in the mixture of ethylene carbonate (EC)/dimethyl carbonate (DMC) (1:1 vol\%). Charge-discharge cycles of cells were measured between 0.01 and $2.0 \mathrm{~V}$ versus $\mathrm{Li}^{+} / \mathrm{Li}$ using a battery test instrument (LAND CT2001A model, Wuhan Jinnuo Electronics, China) at room temperature. Cyclic voltammetry (CV) was conducted on the workstation at a scan rate of $0.1 \mathrm{mV} \mathrm{s}^{-1}$ in a potential range of $5 \mathrm{mV}-2.0 \mathrm{~V}$ (vs. $\mathrm{Li} / \mathrm{Li}^{+}$).

\section{Results and Discussion}

Figure 1 displays the XRD pattern, TGA curve, FESEM, and TEM images of $\mathrm{ZnSn}(\mathrm{OH})_{6}$ precursors. From Fig. 1a, one can see that all of the diffraction peaks of the as-
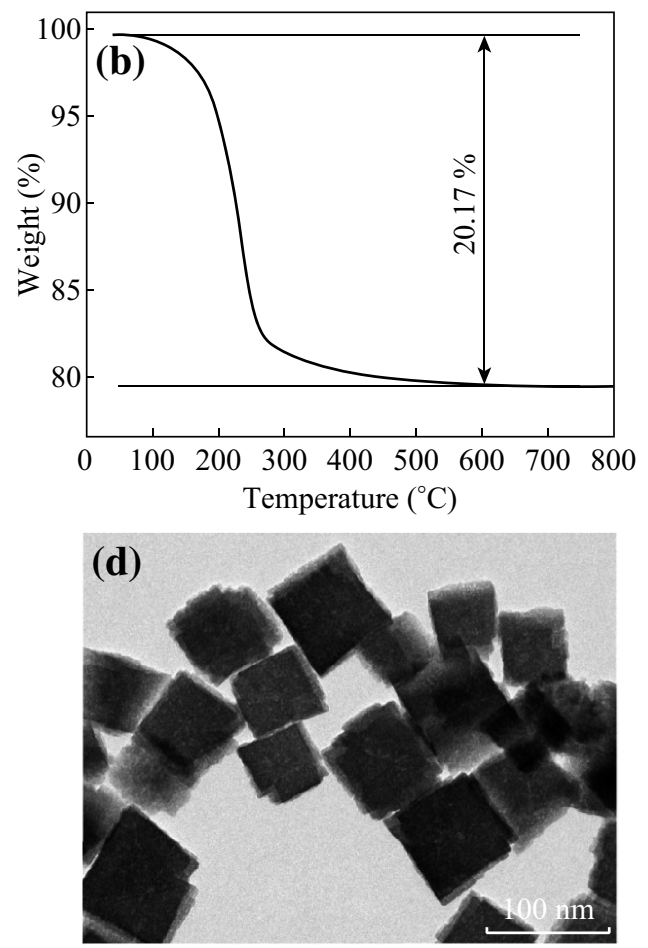

Fig. 1 a XRD pattern, b TGA curve, c FESEM, and d TEM image of the as-prepared $\mathrm{ZnSn}(\mathrm{OH})_{6}$ 
prepared products are in good agreement with the cubic phase of $\mathrm{ZnSn}(\mathrm{OH})_{6}$ (JCPDS CARD No. 20-1455). The sharp peaks imply that the obtained $\mathrm{ZnSn}(\mathrm{OH})_{6}$ particles have good crystallinity, and no impurity phases were observed. Figure $1 \mathrm{~b}$ shows the TGA curve of $\mathrm{ZnSn}(\mathrm{OH})_{6}$, heating from 30 to $800{ }^{\circ} \mathrm{C}$ in air at a rate of $10{ }^{\circ} \mathrm{C} \mathrm{min}{ }^{-1}$. The first weight loss (about $1 \%$ ) occurs in the temperature range of $30-100{ }^{\circ} \mathrm{C}$, corresponding to the removal of water and the residual organic molecular absorbed on samples. The second weight loss $(20.17-1 \%=19.17 \%)$ at high temperature $\left(100-500{ }^{\circ} \mathrm{C}\right)$ is ascribed to the loss of three water molecules according to the following chemical formula:

$\mathrm{ZnSn}(\mathrm{OH})_{6} \rightarrow \mathrm{ZnSnO}_{3}+3 \mathrm{H}_{2} \mathrm{O}$

The theoretical weight loss based on the above formula is about $18.9 \%$, which is consistent with the experimental result. The SEM image (Fig. 1c) shows that the obtained $\mathrm{ZnSn}(\mathrm{OH})_{6}$ is composed of uniform and monodisperse nanocubes with side length of 80-120 $\mathrm{nm}$. The TEM image suggests that the as-prepared $\mathrm{ZnSn}(\mathrm{OH})_{6}$ nanocubes are in solid morphology (Fig. 1d).

The as-prepared $\mathrm{ZnSn}(\mathrm{OH})_{6}$ nanocubes were annealed at 500,600 , and $700{ }^{\circ} \mathrm{C}$ for $2 \mathrm{~h}$, and the calcinated products are marked as $\mathrm{Zn}-\mathrm{Sn}-\mathrm{O}-500, \mathrm{Zn}-\mathrm{Sn}-\mathrm{O}-600$, and $\mathrm{Zn}-\mathrm{Sn}-$ O-700, respectively. From the XRD patterns of products calcined at different temperatures (Fig. 2), it can be seen that only one broad peak is observed for $\mathrm{Zn}-\mathrm{Sn}-\mathrm{O}-500$, suggesting the amorphous nature of the products prepared at $500{ }^{\circ} \mathrm{C}$. When the calcination temperature is $600{ }^{\circ} \mathrm{C}$, three diffraction peaks of $\mathrm{SnO}_{2}$ (JCPDS CARD No. 41-1445) appear for $\mathrm{Zn}-\mathrm{Sn}-\mathrm{O}-600$, indicating a phase transition from amorphous to crystalline. However, the intensity of these peaks is very weak due to the poor crystallinity or some amorphous crystallites of $\mathrm{Zn}-\mathrm{Sn}-\mathrm{O}$ 600. Characteristic peaks of $\mathrm{SnO}_{2}$ and spinal $\mathrm{Zn}_{2} \mathrm{SnO}_{4}$ (JCPDS CARD No. 24-1470) appear for Zn-Sn-O-700 when the calcination temperature was further increased to $700{ }^{\circ} \mathrm{C}$. Considering these facts, the thermal process of

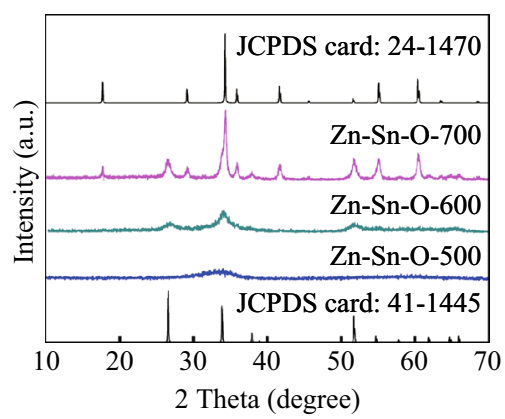

Fig. 2 XRD patterns of $\mathrm{Zn}-\mathrm{Sn}-\mathrm{O}-500, \mathrm{Zn}-\mathrm{Sn}-\mathrm{O}-600$, and $\mathrm{Zn}-\mathrm{Sn}-$ O-700
$\mathrm{ZnSn}(\mathrm{OH})_{6}$ sintered at different temperatures can be proposed as follows:

$500{ }^{\circ} \mathrm{C}: \mathrm{ZnSn}(\mathrm{OH})_{6} \rightarrow \mathrm{ZnSnO}_{3}$ (amorphous) $+3 \mathrm{H}_{2} \mathrm{O}$,

$600{ }^{\circ} \mathrm{C}: 2 \mathrm{ZnSnO}_{3}$ (amorphous)

$\rightarrow \mathrm{Zn}_{2} \mathrm{SnO}_{4}$ (amorphous) $+2 \mathrm{SnO}_{2}$ (crystalline),

$700{ }^{\circ} \mathrm{C}: \mathrm{Zn}_{2} \mathrm{SnO}_{4}$ (amorphous) $+\mathrm{SnO}_{2}$ (crystalline)

$\rightarrow \mathrm{Zn}_{2} \mathrm{SnO}_{4}$ (crystalline) $+\mathrm{SnO}_{2}$ (crystalline)

When sintering at $500{ }^{\circ} \mathrm{C}, \mathrm{ZnSn}(\mathrm{OH})_{6}$ lost three water molecules to form amorphous $\mathrm{ZnSnO}_{3}$. At $600{ }^{\circ} \mathrm{C}$, amorphous $\mathrm{ZnSnO}_{3}$ decomposed into amorphous $\mathrm{Zn}_{2} \mathrm{SnO}_{4}$ and crystalline $\mathrm{SnO}_{2}$. With calcination temperature further increasing to $700{ }^{\circ} \mathrm{C}$, the state of $\mathrm{Zn}_{2} \mathrm{SnO}_{4}$ transferred from amorphous to crystalline.

The morphology and microstructure of the porous $\mathrm{Zn}-$ $\mathrm{Sn}-\mathrm{O}$ nanocubes prepared at different calcination temperatures are shown in Fig. 3. When the as-prepared $\mathrm{ZnSn}(\mathrm{OH})_{6}$ nanocubes were calcined at $500{ }^{\circ} \mathrm{C}$, the morphology of Zn-Sn-O-500 (Fig. 3a) is similar to that of $\mathrm{ZnSn}(\mathrm{OH})_{6}$ precursors (Fig. 1c). After treated at $600{ }^{\circ} \mathrm{C}$, a basic shape of nanocubes can also be maintained (Fig. 3c, $\mathrm{Zn}-\mathrm{Sn}-\mathrm{O}-600)$, whereas some uniform holes on/in the surface or body were formed (Fig. 3d). However, as the temperature increased to $700{ }^{\circ} \mathrm{C}$, the morphology of products became irregular and large holes were observed (Fig. 3e, Zn-Sn-O-700). The formation of porous structure may be due to the removal of water during the thermal decomposition processes.

Figure 4 shows the $\mathrm{N}_{2}$ adsorption/desorption isotherm curves and porous volume distribution of $\mathrm{Zn}-\mathrm{Sn}-\mathrm{O}$ samples. The isotherms have a characteristic of a type IV with type $\mathrm{H} 3$ hysteresis loop, indicating their mesoporous microstructure $[31,32]$. The BET surface areas of $\mathrm{Zn}-\mathrm{Sn}-$ $\mathrm{O}-500, \mathrm{Zn}-\mathrm{Sn}-\mathrm{O}-600$, and $\mathrm{Zn}-\mathrm{Sn}-\mathrm{O}-700$ are calculated to be $31.64,40.01$, and $21.89 \mathrm{~m}^{2} \mathrm{~g}^{-1}$, respectively. The pore size distribution of $\mathrm{Zn}-\mathrm{Sn}-\mathrm{O}-500$ calculated from the $\mathrm{BJH}$ method is in a bimodal nature with a narrow distribution of pore size centered at $3 \mathrm{~nm}$ and a wide distribution of pore size centered at $20 \mathrm{~nm}$. $\mathrm{Zn}-\mathrm{Sn}-\mathrm{O}-600$ has a relatively narrow distribution of pore size centered at $6 \mathrm{~nm}$, indicating a high-uniform pore structure. However, $\mathrm{Zn}-\mathrm{Sn}-\mathrm{O}-$ 700 has a wide distribution of pore size centered at $40 \mathrm{~nm}$.

The properties of the porous $\mathrm{Zn}-\mathrm{Sn}-\mathrm{O}$ nanocubes with different crystallinity, chemical composition, and microstructure as an anode material for LIBs were further studied. To identify the lithium storage mechanism of the porous $\mathrm{Zn}-\mathrm{Sn}-\mathrm{O}$ nanocubes, the cyclic voltammetry of $\mathrm{Zn}-\mathrm{Sn}-\mathrm{O}-600$ was carried out in the voltage range of 

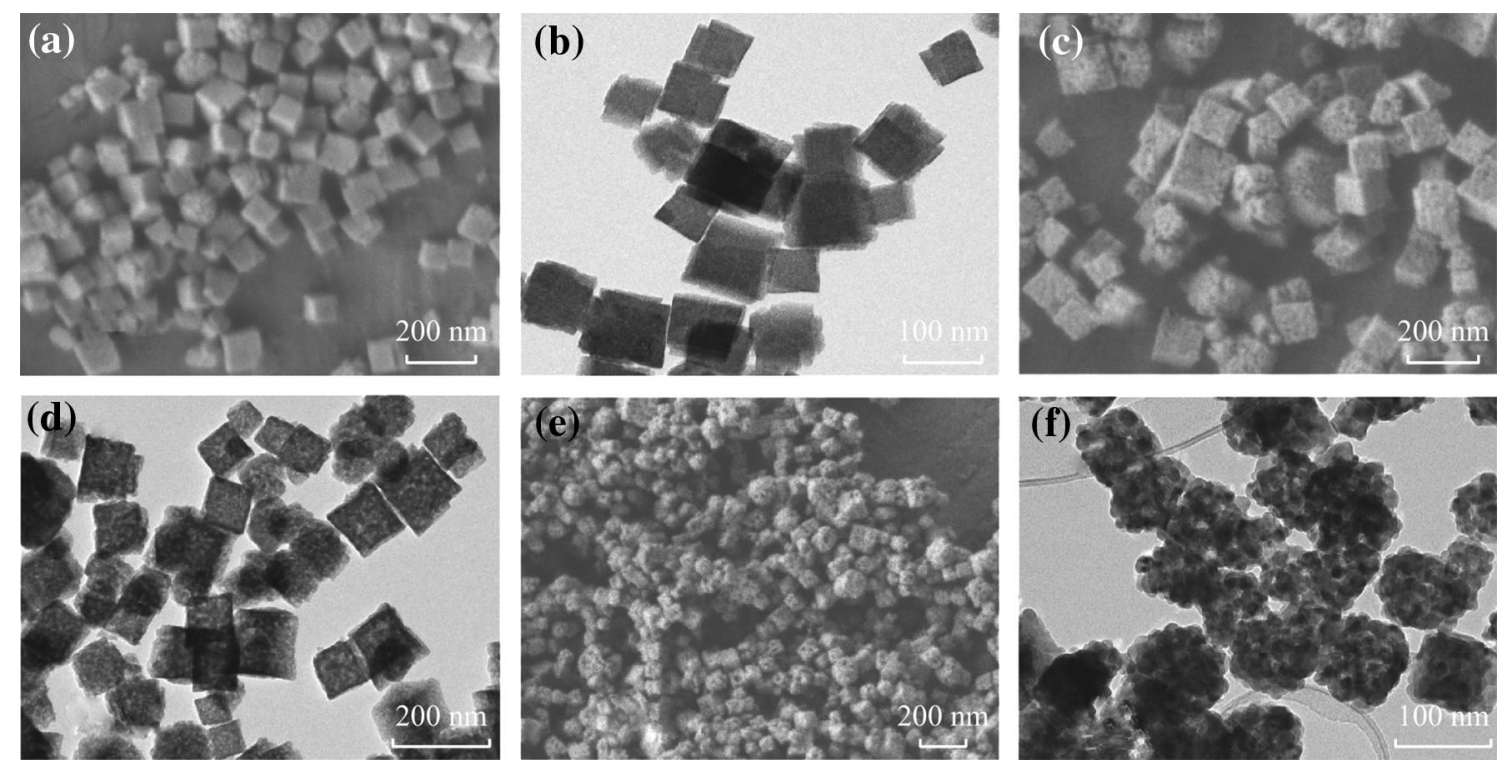

Fig. 3 FESEM images and TEM images of porous $\mathrm{Zn}-\mathrm{Sn}-\mathrm{O}$ nanocubes: a, b Zn-Sn-O-500, c, d Zn-Sn-O-600, and e, f Zn-Sn-O-700
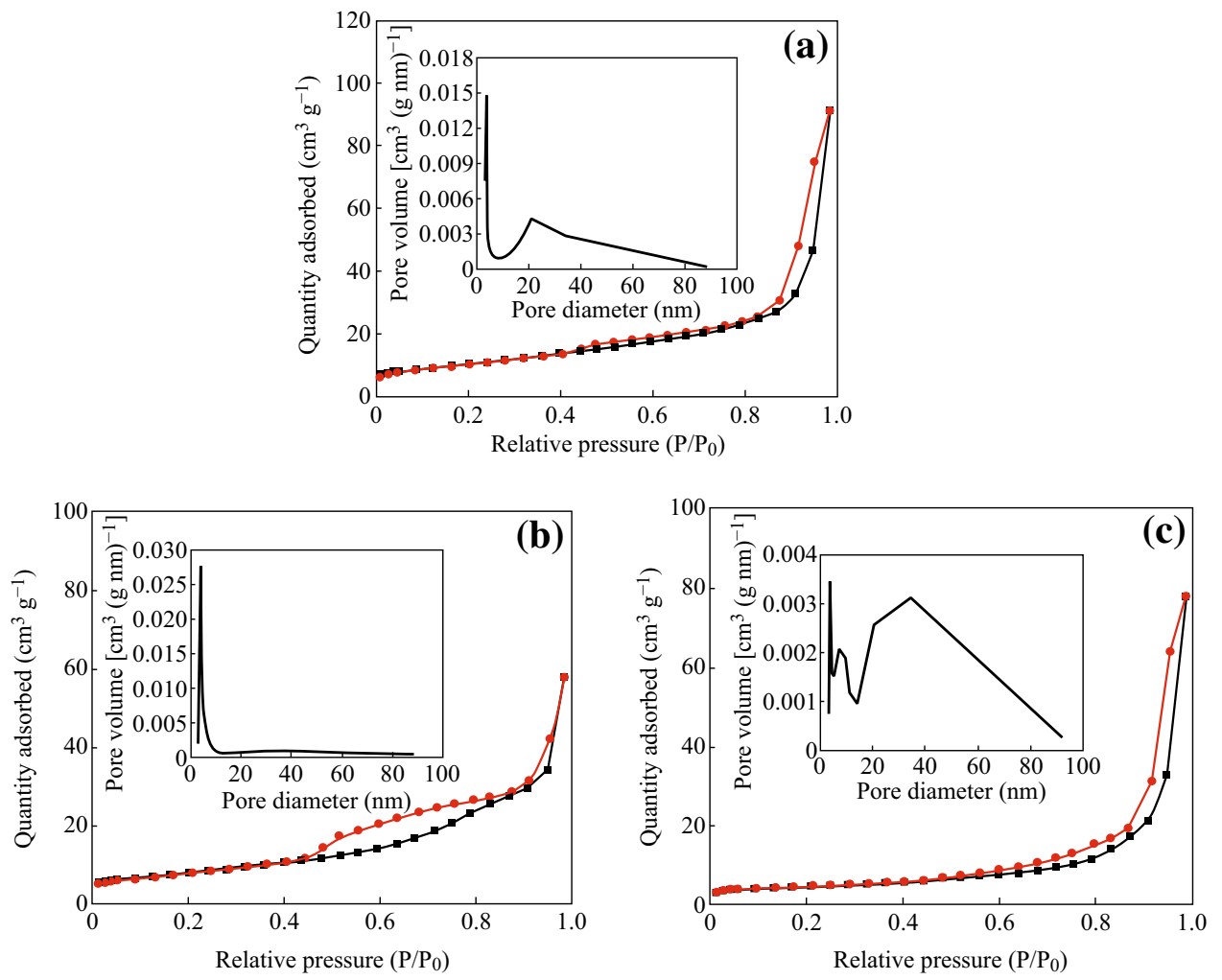

Fig. $4 \mathrm{~N}_{2}$ adsorption/desorption isotherm curves and porous volume distribution of the $\mathrm{Zn}-\mathrm{Sn}-\mathrm{O}$ : a $\mathrm{Zn}-\mathrm{Sn}-\mathrm{O}-500$, b Zn-Sn-O-600, and $\mathbf{c} \mathrm{Zn}-$ Sn-O-700

0.01-2 V (see Fig. 5a). Based on the lithium storage mechanism of $\mathrm{SnO}_{2}$ [16], $\mathrm{ZnO}$ [33], and $\mathrm{Zn}_{2} \mathrm{SnO}_{4}$ [34], a lithium insertion mechanism of $\mathrm{Zn}-\mathrm{Sn}-\mathrm{O}-600$ nanocubes is proposed as follows:

$$
\begin{aligned}
& \mathrm{Zn}_{2} \mathrm{SnO}_{4}+8 \mathrm{Li}^{+}+8 e^{-} \rightarrow \mathrm{Sn}+2 \mathrm{Zn}+4 \mathrm{Li}_{2} \mathrm{O} \\
& \mathrm{SnO}_{2}+4 \mathrm{Li}^{+}+4 e^{-} \rightarrow \mathrm{Sn}+2 \mathrm{Li}_{2} \mathrm{O}
\end{aligned}
$$



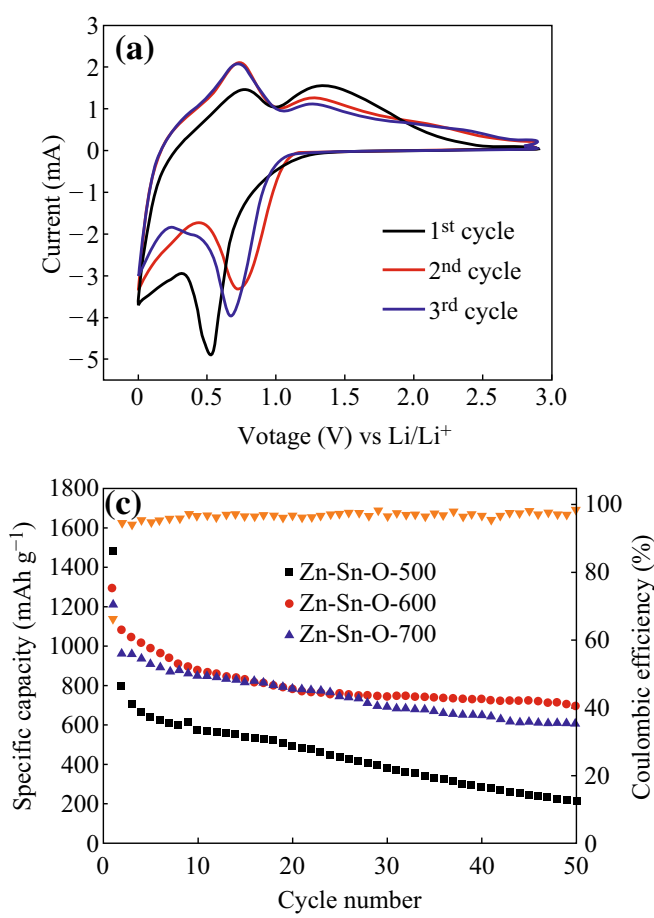
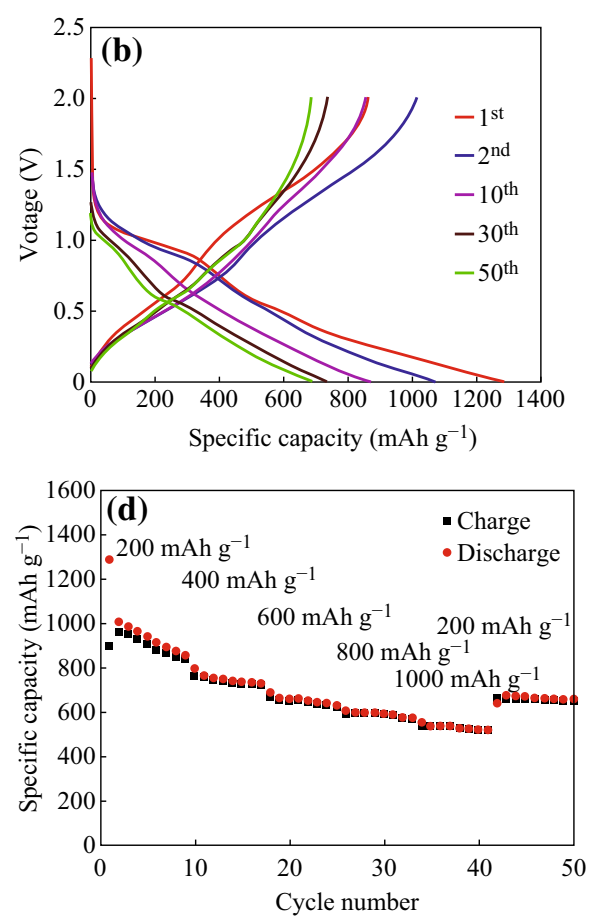

Fig. 5 a CV curves of $\mathrm{Zn}-\mathrm{Sn}-\mathrm{O}-600$ electrode for the first three cycles in the voltage range of $0.01-2.0 \mathrm{~V}$ at scan rate of $0.1 \mathrm{mV} \mathrm{s}{ }^{-1}$; b Chargedischarge profile of $\mathrm{Zn}-\mathrm{Sn}-\mathrm{O}-600$ electrode for the first three cycles in the voltage range of $0.01-2.0 \mathrm{~V}$ at a current density of $200 \mathrm{~mA} \mathrm{~g}^{-1}$; c The cycling performances of the porous $\mathrm{Zn}-\mathrm{Sn}-\mathrm{O}$ nanocubes prepared at different calcination temperatures at a current density of $200 \mathrm{~mA} \mathrm{~g}^{-1}$ between 0.01 and $2.0 \mathrm{~V}$; d Rate performances of $\mathrm{Zn}-\mathrm{Sn}-\mathrm{O}-600$

$\mathrm{Sn}+x \mathrm{Li}^{+} \leftrightarrow \mathrm{Li}_{x} \mathrm{Sn} \quad(0 \leq x \leq 4.4)$

$\mathrm{Zn}+y \mathrm{Li}^{+} \leftrightarrow \mathrm{Li}_{y} \mathrm{Zn} \quad(y \leq 1)$

In the first cycle for $\mathrm{Zn}-\mathrm{Sn}-\mathrm{O}-600$ (Fig. 5a), two cathodic peaks, located at 0.53 and $0.05 \mathrm{~V}$, correspond to the multistep electrochemical lithiation process with the decomposition of $\mathrm{Zn}_{2} \mathrm{SnO}_{4}$ and $\mathrm{SnO}_{2}$ (Eqs. 5 and 6) and the formation of alloys (Eqs. 7 and 8). Meanwhile, the anodic peak at $0.63 \mathrm{~V}$ corresponding to the dealloying reaction and a broad anodic peak at $\sim 1.35 \mathrm{~V}$ are attributed to the oxidation of $\mathrm{Sn}(1.3 \mathrm{~V})$ and $\mathrm{Zn}(1.5 \mathrm{~V})$.

Figure $5 \mathrm{~b}$ depicts the charge/discharge voltage profiles of the 1st, 2nd, 10th, 30th, and 50th cycle for the porous $\mathrm{Zn}-\mathrm{Sn}-\mathrm{O}-600$ nanocubes cycled between 0.01 and $2.0 \mathrm{~V}$ at a current density of $200 \mathrm{~mA} \mathrm{~g}^{-1}$. The initial discharge and charge capacities are about 1290 and $860 \mathrm{mAh} \mathrm{g}^{-1}$, respectively. The large capacity loss in the first cycle is mainly attributed to the initial irreversible formation of $\mathrm{Li}_{2} \mathrm{O}$ and inevitable formation of a solid electrolyte interface (SEI) layer as well as additional reaction from conducting agent, which is common for most anode materials [35-38]. Figure 5c shows the cycling performances of the as-prepared porous $\mathrm{Zn}-\mathrm{Sn}-\mathrm{O}$ nanocubes. The initial discharge capacities are about 1470 (Zn-Sn-O-500), 1290 (Zn-Sn-O-600), and 1230 (Zn-Sn-O-700) $\mathrm{mAh} \mathrm{g}^{-1}$ at the current density of $200 \mathrm{mh} \mathrm{g}^{-1}$. However, the discharge capacity of $\mathrm{Zn}-\mathrm{Sn}-\mathrm{O}-500$ exhibits a rapid decline, and $\mathrm{Zn}-$ Sn-O-700 just maintains $590 \mathrm{mAh} \mathrm{g}^{-1}$ after 50 cycles, while $\mathrm{Zn}-\mathrm{Sn}-\mathrm{O}-600$ can keep around $700 \mathrm{mAh} \mathrm{g}^{-1}$. These results indicate that $\mathrm{Zn}-\mathrm{Sn}-\mathrm{O}-600$ has a better capacity and cycling performance. To evaluate the rate capability of the obtained products, porous $\mathrm{Zn}-\mathrm{Sn}-\mathrm{O}-600$ nanocubes are cycled at various current densities ranging from 200 to $1000 \mathrm{~mA} \mathrm{~g}^{-1}$. From Fig. 5d, one can see that only small capacity decreases as the current density increasing, and a stable reversible capacity of $538 \mathrm{mAh} \mathrm{g}^{-1}$ can be maintained even at a high current density of $1000 \mathrm{~mA} \mathrm{~g}^{-1}$. When the current density returns to $200 \mathrm{~mA} \mathrm{~g}^{-1}$, stable reversible capacity of $663 \mathrm{mAh} \mathrm{g}^{-1}$ can be restored for $\mathrm{Zn}-\mathrm{Sn}-\mathrm{O}-600$, indicating the stability of the porous $\mathrm{Zn}-\mathrm{Sn}-\mathrm{O}$ anode materials.

The improved electrochemical performances of the obtained porous $\mathrm{Zn}-\mathrm{Sn}-\mathrm{O}$ nanocubes could be attributed to their unique nanostructures. Firstly, the void space provided by porous structure can mitigate the volume change effect during the repeated charge-discharge cycling process, leading to enhanced capacity retention. Meanwhile, the narrow pore size and high specific surface area are beneficial to even the electrolyte diffusion and shorten the transport distance of $\mathrm{Li}^{+}$ions, which is benefit for the rate capability [39]. Furthermore, the in situ hybridization of amorphous $\mathrm{Zn}_{2} \mathrm{SnO}_{4}$ and crystalline $\mathrm{SnO}_{2}$ in $\mathrm{Zn}-\mathrm{Sn}-\mathrm{O}-600$ 

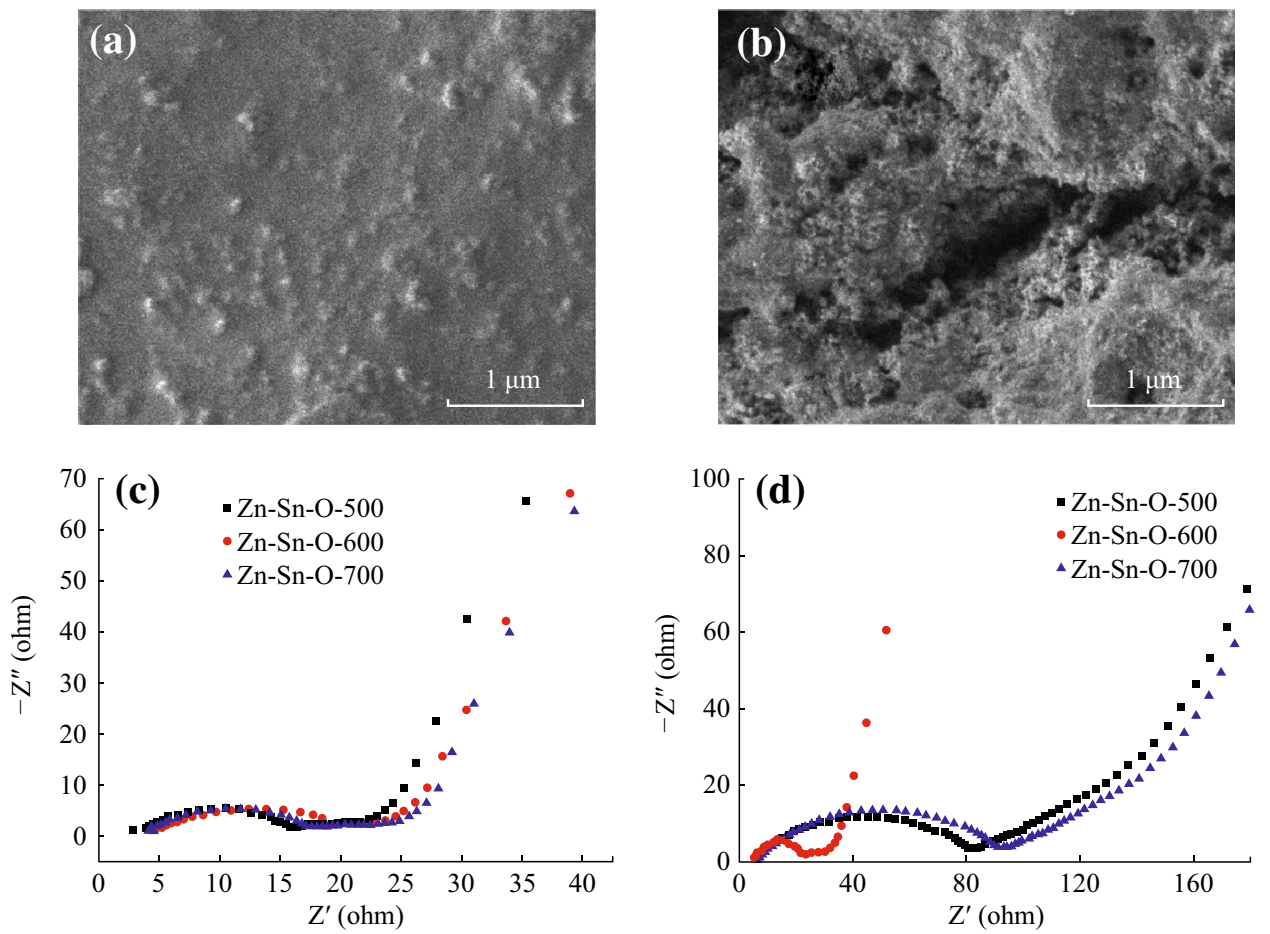

Fig. 6 Surface morphology of the electrodes after 50 cycles: a Zn-Sn-O-600 and b Zn-Sn-O-700. EIS spectra of Zn-Sn-O-500, Zn-Sn-O-600, and $\mathrm{Zn}-\mathrm{Sn}-\mathrm{O}-700$ electrodes: $\mathbf{c}$ after the first cycle, and $\mathbf{d}$ after 50 cycles

may also contribute to their lithium storage performance because the volume change upon cycling can be partly mitigated in an isotropic loose dense structure [18]. The morphology of the electrode after 50 cycles was monitored using SEM images. From which, one can see that $\mathrm{Zn}-\mathrm{Sn}-$ O-600 still maintains unbroken with no significant cracks or delaminations (Fig. 6a), while some cracks were observed on the surface of $\mathrm{Zn}-\mathrm{Sn}-\mathrm{O}-700$ (Fig. 6b), indicating that the electrode structure of $\mathrm{Zn}-\mathrm{Sn}-\mathrm{O}-600$ is more stable over the repeated cycling processes. To provide further evidence, Fig. 6c, d displays the EIS spectra of $\mathrm{Zn}-$ Sn-O-500, Zn-Sn-O-600, and Zn-Sn-O-700 electrodes. The resistance of the three electrodes shows little difference after the first cycle (Fig. 6c). However, the $\mathrm{Zn}-\mathrm{Sn}-\mathrm{O}-$ 500 and $\mathrm{Zn}-\mathrm{Sn}-\mathrm{O}-700$ electrodes exhibit evident impedance changes after 50 cycles (Fig. $6 \mathrm{~d}$ ). In contrast, a very slight change in the resistance of the $\mathrm{Zn}-\mathrm{Sn}-\mathrm{O}-500$ electrode is observed after 50 cycles, confirming the excellent structural stability of the composite upon cycling.

\section{Conclusions}

In summary, a facile, low-cost, and scalable process was developed to synthesize porous $\mathrm{Zn}-\mathrm{Sn}-\mathrm{O}$ nanocubes. The chemical composition, morphology, and microstructure of $\mathrm{Zn}-\mathrm{Sn}-\mathrm{O}$ nanocubes were easily controlled by adjusting the calcination temperature. Electrochemical evaluation reveals that the porous $\mathrm{Zn}-\mathrm{Sn}-\mathrm{O}$ nanocubes prepared at $600{ }^{\circ} \mathrm{C}$ exhibited a good rate capability and high reversible capacity of $700 \mathrm{mAh} \mathrm{g}^{-1}$ at a current density of $200 \mathrm{~mA} \mathrm{~g}^{-1}$ after 50 cycles. Given the synthetic convenience, scalability for quantity production, and better lithium storage property, we believe that the as-prepared porous $\mathrm{Zn}-\mathrm{Sn}-\mathrm{O}$ nanocubes could elicit widespread interest in lithium-ion batteries or other significant applications.

Acknowledgments This work is supported by the National Basic Research Program of China (2014CB239700), the Program of National Natural Science Foundation of China (21501120, 21371121 and 21331004), and Science and Technology Commission of Shanghai Municipality (14DZ1205700 and 14DZ2250800).

Open Access This article is distributed under the terms of the Creative Commons Attribution 4.0 International License (http://crea tivecommons.org/licenses/by/4.0/), which permits unrestricted use, distribution, and reproduction in any medium, provided you give appropriate credit to the original author(s) and the source, provide a link to the Creative Commons license, and indicate if changes were made.

\section{References}

1. B. Scrosati, J. Garche, Lithium batteries: status, prospects and future. J. Power Sources 195(9), 2419-2430 (2010). doi:10.1016/ j.jpowsour.2009.11.048

2. J.-M. Tarascon, M. Armand, Issues and challenges facing rechargeable lithium batteries. Nature 414(6861), 359-367 (2001). doi:10.1038/35104644 
3. L. Ji, Z. Lin, M. Alcoutlabi, X. Zhang, Recent developments in nanostructured anode materials for rechargeable lithium-ion batteries. Energy Environ. Sci. 4(8), 2682-2699 (2011). doi:10. 1039/c0ee00699h

4. K. Kang, Y.S. Meng, J. Bréger, C.P. Grey, G. Ceder, Electrodes with high power and high capacity for rechargeable lithium batteries. Science 311(5763), 977-980 (2006). doi:10.1126/sci ence. 1122152

5. M.S. Whittingham, Lithium batteries and cathode materials. Chem. Rev. 104(10), 4271-4302 (2004). doi:10.1021/cr020731c

6. M. Winter, J.O. Besenhard, M.E. Spahr, P. Novak, Insertion electrode materials for rechargeable lithium batteries. Adv. Mater. 10(10), 725-763 (1998). doi:10.1002/(SICI)15214095(199807)10:10<725:AID-ADMA725>3.0.CO;2-Z

7. Y. Idota, T. Kubota, A. Matsufuji, Y. Maekawa, T. Miyasaka, Tin-based amorphous oxide: a high-capacity lithium-ion-storage material. Science 276(5317), 1395-1397 (1997). doi:10.1126/sci ence. 276.5317 .1395

8. R. Wright, J. Christophersen, C. Motloch, J. Belt, C. Ho, V. Battaglia, J. Barnes, T. Duong, R. Sutula, Power fade and capacity fade resulting from cycle-life testing of advanced technology development program lithium-ion batteries. J. Power Sources 119-121， 865-869 (2003). doi:10.1016/S03787753(03)00190-3

9. Y.G. Guo, J.S. Hu, L.J. Wan, Nanostructured materials for electrochemical energy conversion and storage devices. Adv. Mater. 20(15), 2878-2887 (2008). doi:10.1002/adma.200800627

10. X.W.D. Lou, L.A. Archer, Z. Yang, Hollow micro-nanostructures: synthesis and applications. Adv. Mater. 20(21), 3987-4019 (2008). doi:10.1002/adma.200800854

11. J. Jiang, Y. Li, J. Liu, X. Huang, C. Yuan, X.W.D. Lou, Recent advances in metal oxide-based electrode architecture design for electrochemical energy storage. Adv. Mater. 24(38), 5166-5180 (2012). doi:10.1002/adma.201202146

12. F.-H. Du, K.-X. Wang, W. Fu, P.-F. Gao, J.-F. Wang, J. Yang, J.S. Chen, A graphene-wrapped silver-porous silicon composite with enhanced electrochemical performance for lithium-ion batteries. J. Mater. Chem. A 1(43), 13648-13654 (2013). doi:10. 1039/c3ta13092d

13. J. Zai, K. Wang, Y. Su, X. Qian, J. Chen, High stability and superior rate capability of three-dimensional hierarchical $\mathrm{SnS}_{2}$ microspheres as anode material in lithium ion batteries. J. Power Sources 196(7), 3650-3654 (2011). doi:10.1016/j.jpowsour.2010. 12.057

14. Y. Xiao, X. Li, J. Zai, K. Wang, Y. Gong, B. Li, Q. Han, X. Qian, $\mathrm{CoFe}_{2} \mathrm{O}_{4}$-graphene nanocomposites synthesized through an ultrasonic method with enhanced performances as anode materials for li-ion batteries. Nano-Micro Lett. 6(4), 307-315 (2014). doi:10.1007/s40820-014-0003-7

15. X. Zhang, J. Ma, K. Chen, Impact of morphology of conductive agent and anode material on lithium storage properties. NanoMicro Lett. 7(4), 360-367 (2015). doi:10.1007/s40820-015-00517

16. J.S. Chen, X.W.D. Lou, $\mathrm{SnO}_{2}$-based nanomaterials: synthesis and application in lithium-ion batteries. Small 9(11), 1877-1893 (2013). doi:10.1002/smll.201202601

17. S. Ding, D. Luan, F.Y.C. Boey, J.S. Chen, X.W.D. Lou, $\mathrm{SnO}_{2}$ nanosheets grown on graphene sheets with enhanced lithium storage properties. Chem. Commun. 47(25), 7155-7157 (2011). doi:10.1039/c1cc11968k

18. Z. Wang, Z. Wang, W. Liu, W. Xiao, X.W.D. Lou, Amorphous $\mathrm{CoSnO}_{3} @ \mathrm{C}$ nanoboxes with superior lithium storage capability. Energy Environ. Sci. 6(1), 87-91 (2013). doi:10.1039/ C2EE23330D

19. Y. Chen, B. Qu, L. Mei, D. Lei, L. Chen, Q. Li, T. Wang, Synthesis of $\mathrm{ZnSnO}_{3}$ mesocrystals from regular cube-like to sheet-like structures and their comparative electrochemical properties in Li-ion batteries. J. Mater. Chem. 22(48), 25373-25379 (2012). doi:10.1039/c2jm33123c

20. A. Rong, X. Gao, G. Li, T. Yan, H. Zhu, J. Qu, D. Song, Hydrothermal synthesis of $\mathrm{Zn}_{2} \mathrm{SnO}_{4}$ as anode materials for $\mathrm{Li}$-ion battery. J. Phys. Chem. B 110(30), 14754-14760 (2006). doi:10. 1021/jp062875r

21. G.-L. Xu, S.-R. Chen, J.-T. Li, F.-S. Ke, L. Huang, S.-G. Sun, A composite material of $\mathrm{SnO}_{2}$ ordered mesoporous carbon for the application in Lithium-ion battery. J. Electroanal. Chem. 656(1), 185-191 (2011). doi:10.1016/j.jelechem.2010.11.029

22. D. Larcher, S. Beattie, M. Morcrette, K. Edstroem, J.-C. Jumas, J.-M. Tarascon, Recent findings and prospects in the field of pure metals as negative electrodes for Li-ion batteries. J. Mater. Chem. 17(36), 3759-3772 (2007). doi:10.1039/b705421c

23. X. Zhu, L. Geng, F. Zhang, Y. Liu, L. Cheng, Synthesis and performance of $\mathrm{Zn}_{2} \mathrm{SnO}_{4}$ as anode materials for lithium ion batteries by hydrothermal method. J. Power Sources 189(1), 828-831 (2009). doi:10.1016/j.jpowsour.2008.07.028

24. L. Yuan, Z. Guo, K. Konstantinov, H.K. Liu, S. Dou, Nanostructured spherical porous $\mathrm{SnO}_{2}$ anodes for lithium-ion batteries. J. Power Sources 159(1), 345-348 (2006). doi:10.1016/j.jpow sour.2006.04.048

25. L. Li, X. Yin, S. Liu, Y. Wang, L. Chen, T. Wang, Electrospun porous $\mathrm{SnO}_{2}$ nanotubes as high capacity anode materials for lithium ion batteries. Electrochem. Commun. 12(10), 1383-1386 (2010). doi:10.1016/j.elecom.2010.07.026

26. M. Marcinek, L. Hardwick, T. Richardson, X. Song, R. Kostecki, Microwave plasma chemical vapor deposition of nano-structured $\mathrm{Sn} / \mathrm{C}$ composite thin-film anodes for Li-ion batteries. J. Power Sources 173(2), 965-971 (2007). doi:10.1016/j.jpowsour.2007. 08.084

27. Z. Wen, Q. Wang, Q. Zhang, J. Li, In situ growth of mesoporous $\mathrm{SnO}_{2}$ on multiwalled carbon nanotubes: a novel composite with porous-tube structure as anode for lithium batteries. Adv. Funct. Mater. 17(15), 2772-2778 (2007). doi:10.1002/adfm.200600739

28. Y. Wang, H.C. Zeng, J.Y. Lee, Highly reversible lithium storage in porous $\mathrm{SnO}_{2}$ nanotubes with coaxially grown carbon nanotube overlayers. Adv. Mater. 18(5), 645-649 (2006). doi:10.1002/ adma.200501883

29. X.M. Yin, C.C. Li, M. Zhang, Q.Y. Hao, S. Liu, L.B. Chen, T.H. Wang, One-step synthesis of hierarchical $\mathrm{SnO}_{2}$ hollow nanostructures via self-assembly for high power lithium ion batteries. J. Phys. Chem. C 114(17), 8084-8088 (2010). doi:10.1021/ jp100224x

30. H. Kim, J. Cho, Hard templating synthesis of mesoporous and nanowire $\mathrm{SnO}_{2}$ lithium battery anode materials. J. Mater. Chem. 18(7), 771-775 (2008). doi:10.1039/b714904b

31. M. Xu, F. Wang, M. Zhao, S. Yang, X. Song, Molten hydroxides synthesis of hierarchical cobalt oxide nanostructure and its application as anode material for lithium ion batteries. Electrochim. Acta 56(13), 4876-4881 (2011). doi:10.1016/j.electacta. 2011.03.027

32. C. Wang, Y. Zhou, M. Ge, X. Xu, Z. Zhang, J. Jiang, Large-scale synthesis of $\mathrm{SnO}_{2}$ nanosheets with high lithium storage capacity. JACS 132(1), 46-47 (2009). doi:10.1021/ja909321d

33. H. Wang, Q. Pan, Y. Cheng, J. Zhao, G. Yin, Evaluation of ZnO nanorod arrays with dandelion-like morphology as negative electrodes for lithium-ion batteries. Electrochim. Acta 54(10), 2851-2855 (2009). doi:10.1016/j.electacta.2008.11.019

34. N. Feng, S. Peng, X. Sun, L. Qiao, X. Li, P. Wang, D. Hu, D. He, Synthesis of monodisperse single crystal $\mathrm{Zn}_{2} \mathrm{SnO}_{4}$ cubes with high lithium storage capacity. Mater. Lett. 76, 66-68 (2012). doi:10.1016/j.matlet.2012.02.071

35. X.W. Lou, Y. Wang, C. Yuan, J.Y. Lee, L.A. Archer, Templatefree synthesis of $\mathrm{SnO}_{2}$ hollow nanostructures with high lithium 
storage capacity. Adv. Mater. 18(17), 2325-2329 (2006). doi:10. 1002/adma.200600733

36. S. Han, B. Jang, T. Kim, S.M. Oh, T. Hyeon, Simple synthesis of hollow tin dioxide microspheres and their application to lithiumion battery anodes. Adv. Funct. Mater. 15(11), 1845-1850 (2005). doi:10.1002/adfm.200500243

37. L.-S. Zhang, L.-Y. Jiang, H.-J. Yan, W.D. Wang, W. Wang, W.G. Song, Y.-G. Guo, L.-J. Wan, Mono dispersed $\mathrm{SnO}_{2}$ nanoparticles on both sides of single layer graphene sheets as anode materials in Li-ion batteries. J. Mater. Chem. 20(26), 5462-5467 (2010). doi:10.1039/c0jm00672f
38. M. Ahmad, S. Yingying, A. Nisar, H. Sun, W. Shen, M. Wei, J. $\mathrm{Zhu}$, Synthesis of hierarchical flower-like $\mathrm{ZnO}$ nanostructures and their functionalization by $\mathrm{Au}$ nanoparticles for improved photocatalytic and high performance Li-ion battery anodes. J. Mater. Chem. 21(21), 7723-7729 (2011). doi:10.1039/ c1jm10720h

39. H. Liu, D. Su, R. Zhou, B. Sun, G. Wang, S.Z. Qiao, Highly ordered mesoporous $\mathrm{MoS}_{2}$ with expanded spacing of the (002) crystal plane for ultrafast lithium ion storage. Adv. Energy Mater. 2(8), 970-975 (2012). doi:10.1002/aenm.201200087 